\title{
Radiographic and ultrasonographic evaluation of the esophagus in the horse
}

\section{Radiografisch en echografisch onderzoek van de slokdarm bij het paard}

\author{
${ }^{1}$ K. Palmers, ${ }^{2}$ E. Van der Vekens, ${ }^{3}$ E. Paulussen, ${ }^{4}$ MT. Picavet, \\ ${ }^{3}$ B. Pardon, ${ }^{3}$ G. van Loon \\ ${ }^{1}$ Equine Hospital De Morette, Edingsesteenweg 237, B-1730 Asse, Belgium \\ ${ }^{2}$ Department of Veterinary Medical Imaging and Small Animal Orthopedics, Ghent University, \\ Faculty of Veterinary Medicine, Salisburylaan 133, B-9820 Merelbeke, Belgium \\ ${ }^{3}$ Department of Large Animal Internal Medicine, \\ Ghent University, Faculty of Veterinary Medicine, Salisburylaan 133, B-9820 Merelbeke, Belgium \\ ${ }^{4}$ DBP Veterinary Services, Spelonckvaart 44, B-9180 Moerbeke-Waas, Belgium
}

\section{katrien.palmers@gmail.com}

\section{$\Lambda_{\text {bstract }}$}

The purpose of this study was to describe the radiographic and ultrasonographic appearance of the esophagus of ten healthy horses. Contrast radiography showed variations in the long-axis shape of the esophagus at the thoracic inlet. Administration of a large volume contrast medium by intubation showed stasis of contrast material for several minutes in two of the ten horses. The wall thickness of the non-distended esophagus on ultrasound was $2.6 \pm 0.3 \mathrm{~mm}$ with significant differences depending on the location. Distention of the esophagus by intubation or by a bolus of water or concentrate resulted in a decrease in wall thickness and it facilitated measuring with less variation. Stasis at the thoracic inlet was seen in five of the ten horses, when a water bolus was administered. Ultrasonographic evaluation of $100 \mathrm{~g}$ spontaneously swallowed commercial concentrate was better than fluid (water bolus or $2.5 \mathrm{~mL} / \mathrm{kg}$ contrast medium) administration via intubation to assess esophageal motility at the thoracic inlet. Stasis seen at the thoracic inlet after bolus administration by intubation should not be regarded as an abnormal finding, and swallowing, with the subsequent peristaltic wave, has a positive influence on the bolus passage time.

\section{SAMENVATTING}

In deze studie worden de radiografische en echografische bevindingen van de slokdarm bij tien gezonde paarden beschreven. Bij contrastradiografie varieerde de vorm van de slokdarm over de lengteas ter hoogte van de borstingang tussen de paarden. Twee van de tien paarden vertoonden stase van contrast ter hoogte van de borstingang gedurende meerdere minuten na de toediening van een groot volume contrast met een slokdarmsonde. Op echografie was de wanddikte van de niet-uitgezette slokdarm $2.6 \pm 0.3 \mathrm{~mm}$ met significante verschillen naar gelang de metingsplaats. Het dilateren van de slokdarm met een sonde, een bolus water of krachtvoer, resulteerde in een dunnere wanddikte en vergemakkelijkte de meting met minder variatie. Na het opgieten van een bolus water was er stase te zien ter hoogte van de borstingang bij vijf van de tien paarden. Het echografisch beoordelen van de slokdarmmotiliteit ter hoogte van de borstingang leek het betrouwbaarst door de passage van een krachtvoerbolus te evalueren. Stase ter hoogte van de borstingang veroorzaakt door het opgieten van een bolus vloeistof is niet abnormaal en de peristaltische golf volgend op een slikbeweging heeft een positieve invloed op de transittijd van een bolus.

\section{INTRODUCTION}

Esophageal obstruction in horses is generally caused by impaction of food material, due to too rapid ingestion and poor mastication of food material or due to ingestion of inappropriate material such as un- soaked beet pulp (Hillyer, 1995; Feige et al., 2000). These impactions most commonly occur in the skeletal muscle portion at the postpharyngeal area or at the thoracic inlet (Hillyer, 1995; Jones and Blikslager, 2004). The diagnosis is usually made by the typical clinical signs, such as bilateral alimentary nasal dis- 
charge and the presence of an obstruction at nasogastric intubation. The condition can be easily confirmed by endoscopy, which also allows identification of mucosal damage after resolution of the obstruction (Hillyer, 1995; Feige et al., 2000; Jones and Blikslager, 2004).

Rarely, recurrent obstruction occurs due to an underlying pathology, such as esophageal stricture, esophageal diverticulum, mega-esophagus, esophageal perforation/rupture, esophageal compression by an external process, congenital/developmental esophageal abnormalities or esophageal neoplasia (Hillyer, 1995; Broekman et al., 2002; Ploeg et al., 2014; Feige et al., 2000; Jones and Blikslager, 2004).

In those cases, endoscopy and (contrast) radiography should be performed. Only limited information on contrast radiography in normal horses is available (Butler et al., 2000; Greet, 1982; Greet and Whitwell, 1986; King et al., 1990), which can make the interpretation of subtle changes, such as stasis or variation in anatomic conformation, difficult. Ultrasonographic examination allows the visualization of the cervical part of the esophagus. Although basic descriptions of ultrasound examination of the equine esophagus are available, quantitative characterization is lacking (Magri et al., 2014; Reef, 1998). Esophageal motility has been evaluated by means of videofluoroscopy and manometry. However, this usually occurred under experimental conditions to standardize the test (Greet, 1982; Stick et al., 1983; Greet and Whitwell, 1986; Clark et al., 1987) or to evaluate the influence of drugs on esophageal motility (Watson and Sullivan, 1991; Meyer et al., 2000; Wooldridge et al., 2002).

The purpose of this study is to describe the radiographic and ultrasonographic appearance of the normal esophagus with emphasis on the cervical part and the thoracic inlet and to establish an easy-to-perform screening test to evaluate the esophageal motility when videofluoroscopy or manometry are not available.

\section{MATERIALS AND METHODS}

A cross-sectional study was conducted involving ten healthy horses without history of esophageal disease. Animals were conveniently selected and were part of the teaching heard of the Faculty of Veterinary Medicine, Ghent University (mean age 13 years; mean weight $556 \mathrm{~kg}$; six mares and four geldings). All horses were examined endoscopically to exclude visible structural abnormalities of the pharynx, larynx and esophagus. The esophagus was examined by radiography and ultrasonography. All examinations were done with at least three days in between the different examinations to avoid interference of possibly altered esophageal motility due to any of the procedures. The experimental protocol of the present study was approved by the Research Ethics Committee of Ghent University, Belgium (EC 2014/21).

\section{Radiography}

All images were acquired using a computed radiography unit (AGFA CR30-Xm and CR12-X, Agfa Healthcare, Belgium ). The $\mathrm{kVp}$ and $\mathrm{mAs}$ ranged from 70 to 120 and 6.4 to 200 , respectively, for the various views. The source to image distance was kept constant at $115 \mathrm{~cm}$.

For each horse, four radiographic studies were performed without sedation. All the studies were performed on the same day and in the same chronological order.

Radiographic examination (RX)1 consisted of five native radiographic left-to-right views of the entire esophagus: the cranial cervical esophagus (view 1), the mid cervical esophagus (view 2), the caudal cervical esophagus with the thoracic inlet (centered $5 \mathrm{~cm}$ dorsal to the scapulohumeral joint) (view 3), the cranial thoracic esophagus dorsal to the heart (view 4) and the caudodorsal lung field imaging the caudal part of the thoracic esophagus entering the diaphragm (view 5).

Radiographic examination RX2 was performed 5 to 10 seconds after swallowing $50 \mathrm{~mL} 100 \%$ barium suspension (Micropaque suspension ${ }^{\circledR}$ Guerbet, Belgium) administered with a $60 \mathrm{~mL}$ syringe (Terumo Europe, Leuven, Belgium). Subsequently, the entire esophagus was radiographed from cranial (view 1) towards caudal (view 5), as described in RX1. The disappearance of the contrast medium was verified by radiography before examination $\mathrm{RX} 3$ was performed.

In examination RX3, an esophageal tube $(16 \mathrm{~mm}$ diameter, $120 \mathrm{~cm}$ length) was inserted via the right nostril and placed in the cranial esophagus. Subsequently, a bolus of $2.5 \mathrm{~mL} / \mathrm{kg}$ body weight $30 \%$ barium was administered with a stomach pump (Equivet metal stomach pump, Kruuse, Denmark) over 15 seconds. The radiographs were centered at the thoracic inlet (view 3 ) and the first radiograph was taken during the last 5 seconds of bolus administration and then repeatedly every 1 to 2 minutes until the contrast medium disappeared completely.

Examination RX4 consisted of the same protocol as examination RX3, but this time, radiographs were centered at the caudal thoracic part of the esophagus (view 5).

During each examination, the anatomic position of the esophagus and its long-axis shape were noted and in RX3 and RX4, the time of disappearance of the contrast medium was registered. This was defined in agreement, by two observers as the time between the radiograph during bolus administration and the first radiograph, at which only traces of contrast medium were seen in between the mucosal folds.

\section{Ultrasound}

For ultrasonography, the horses were restrained in stocks without sedation. The left jugular groove was clipped, cleaned with soap and alcohol, and water 


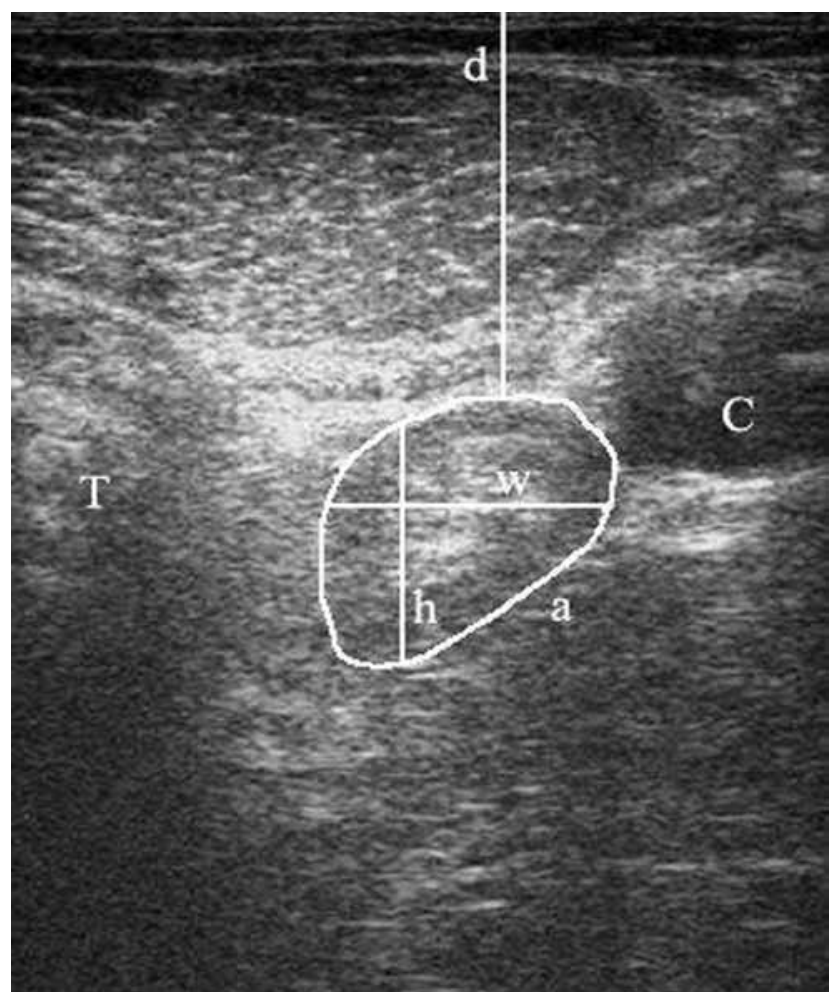

Figure 1. Sonogram of the esophagus from the caudal cervical position, near the thoracic inlet. The esophagus is located ventromedial to the left common carotid artery $(C)$ and dorsal to the trachea (T). The depth from the skin (d), laterolateral width (w), dorsoventral height (h) and surface area (a) are indicated. This sonogram was obtained with a 7.5 MHz linear transducer at displayed depth of 7 $\mathrm{cm}$. The right side of the image is dorsal.

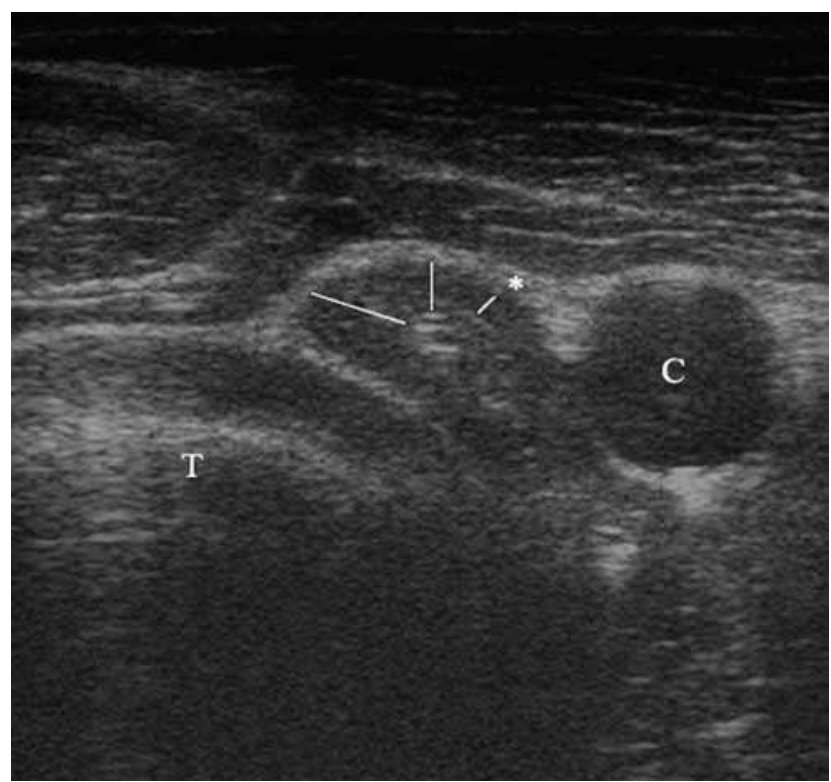

Figure 2. Sonogram of the mid cervical esophagus showing the difference in wall thickness depending on the measurement site. The smallest wall thickness in the near field (*) was always used to assess the esophageal wall. The esophagus is located dorsolateral to the trachea $(T)$ and ventral to the left carotid artery $(C)$. This sonogram was obtained with a $7.5 \mathrm{MHz}$ linear transducer at displayed depth of $7 \mathrm{~cm}$. The right side of the image is dorsal. (C: left common carotid artery; T: trachea). soluble coupling gel was applied. At three standardized locations, transverse images of the esophagus were made using a $7.5 \mathrm{MHz}$ linear array transducer (MyLab 30 VET gold, Esaote, Italy) located at the jugular groove and perpendicular to the long-axis of the neck. The sonographic appearance of the cervical part of the esophagus and its anatomic relation to the trachea and the left common carotid artery were recorded. The first position was $10 \mathrm{~cm}$ caudal to the mandible, the second one was as close as possible to the thoracic inlet and the third position was in the middle of the neck halfway in between the first and second position. A minimum of three ultrasonographic cineloops of 10 seconds were obtained at each site. Images were stored digitally for later analysis (Osirix DICOM Imaging software Pixmeo, Switzerland). Measurements were performed on a still frame.

In every horse, four ultrasonographic examinations were performed in the following order.

Ultrasonographic examination (US) 1 consisted of native images on the three standardized locations. Measurements of the esophagus consisted of depth from the skin, surface area, laterolateral width, dorsoventral height and wall thickness (Figure 1). The wall thickness was measured from the start of the muscularis (hypoechoic layer) to the mucosal surface (hyperechoic luminal-mucosal interface). The smallest wall thickness was chosen on the side of the esophagus in the near field of the transducer (Figure 2). Care was taken to avoid measurements of the wall where it was compressed by the common carotid artery.

In examination US2, a stomach tube (Portex $16 \mathrm{~mm}$ ) was placed in the cranial esophagus $10 \mathrm{~cm}$ caudal to the mandible. The tube was prefilled with water to avoid passage of air during recording. Thereafter, a $250 \mathrm{~mL}$ bolus of water was administered with a funnel, held at a height of $2.3 \mathrm{~m}$ to approximate the same gravitational pressure for every bolus. This was repeated five times: three cineloops were recorded at the thoracic inlet and two cineloops were recorded at the mid cervical region. Before a new bolus was administered, it was verified by means of ultrasound that all the water from the previous bolus had disappeared. The duration of the bolus passage was recorded from the moment of opening of the esophagus at the site of recording by the bolus until complete disappearance of all water. The esophageal wall thickness was measured during maximal distention. Attention was paid to swallowing movements to determine any possible influence on the bolus passage time.

Subsequently, in examination US3, the tube was advanced into the stomach. Similarly, the esophageal wall thickness was measured and its anatomic relation to the trachea and the left common carotid artery was recorded at the three standardized locations.

Examination US4 was performed at least 24 hours after examination US3. In this examination, the horses were fed $100 \mathrm{~g}$ of commercial concentrate food, consisting of a mixture of pelleted grain and corn flakes to evaluate the bolus passage after active swallowing. 
For every horse, three cineloops were made at the level of the thoracic inlet and the duration of the bolus passage was recorded from the moment of opening of the esophagus at the site of recording by the bolus until complete disappearance of the bolus. The esophageal wall thickness was measured during maximal distention.

\section{Statistical analyses}

The unit of analysis was the single measurement within a horse. All outcome variables were checked for a normal distribution. To determine the effect of location (cranial, middle or caudal) on the depth of the esophagus, diameter (laterolateral and dorsoventral), and the wall thickness with and without stomach tube placement, a linear mixed regression model (maximum likelihood) was built (PROC MIXED). In each model, 'horse' was added as a random effect to account for clustering of measurements within a horse. Posthoc pairwise comparisons were performed using Bonferroni corrections. To determine the effect of the tube placement and bolus administration on wall thickness, a linear mixed model with 'horse' as a random factor and 'tube placement' added as a repeated effect was built (PROC MIXED). The significance was set at $\mathrm{P}<0.05$. All analyses were done in SAS 9.4 (SAS Institute, Cary, NC).

\section{RESULTS}

\section{Radiography}

On the native views of examination RX1, the esophagus was difficult to differentiate from the surrounding tissue.

The administration of $50 \mathrm{~mL}$ barium administered with a $60 \mathrm{~mL}$ syringe (Terumo Europe, Leuven, Belgium) in examination RX2 enabled the visualization of the complete course of the esophagus, accentuating the mucosal lining. In all horses, it was located dorsal to the trachea in the cranial to mid cervical part, ventral to the trachea in the caudal cervical part and again dorsal to the trachea in the cranial part of the thorax (superimposed by the scapula). No accumulation of

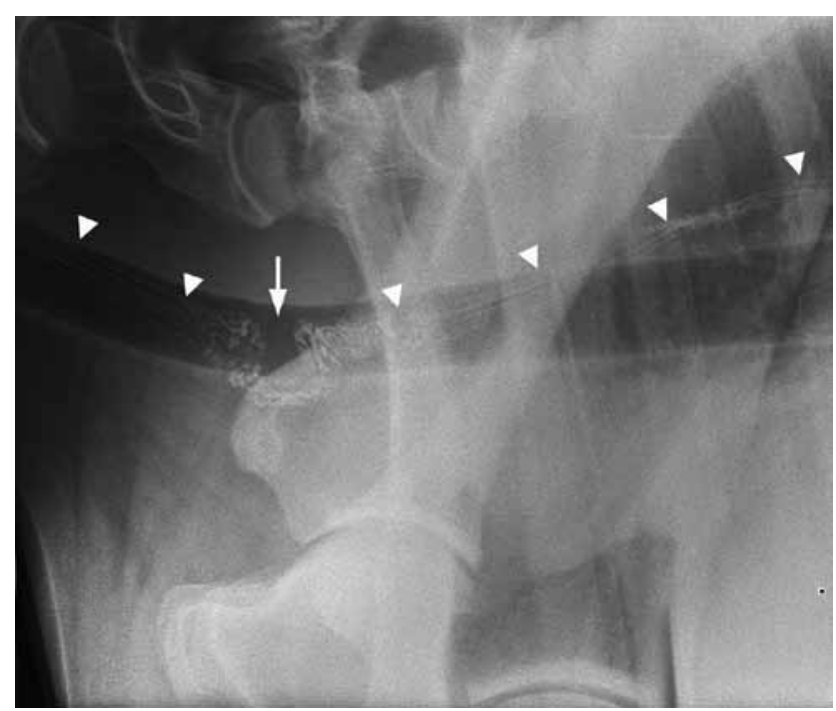

Figure 3. Laterolateral radiograph of the thoracic inlet after administration of $50 \mathrm{~mL} \mathbf{1 0 0} \%$ barium. The mucosal lining is accentuated by barium (arrowheads). In horse 7 , the esophagus has a $U$ shaped deviation (arrow).

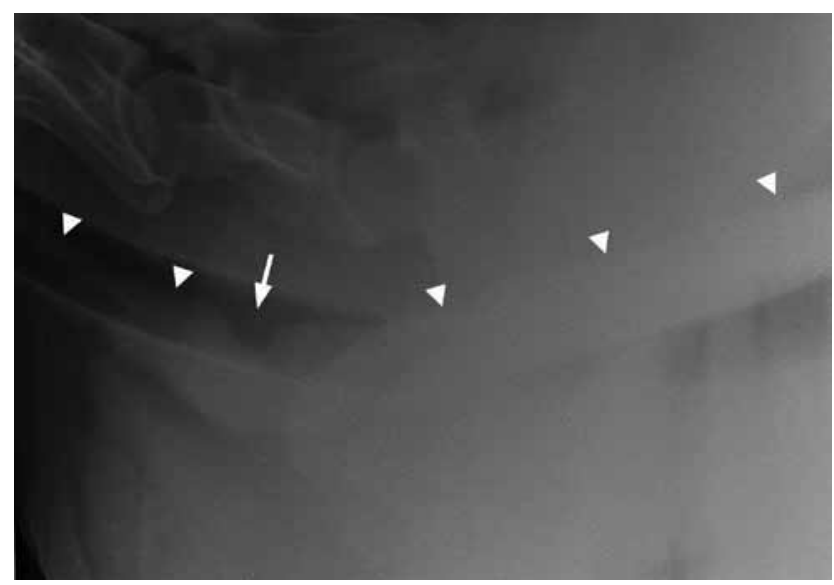

Figure 4. Laterolateral radiograph of the thoracic inlet during bolus administration of $2.5 \mathrm{~mL} / \mathrm{kg} 30 \%$ barium given by intubation. A dorsal filling defect (arrow) was seen in the esophagus (arrowhead) of horse 5.

contrast material was noted on any of the views and the contrast medium remained sufficiently visible to take the five views of the esophagus in 10 minutes. A variation in the long-axis shape of the esophagus

Table 1. Ultrasonographic measurements (mean \pm standard deviation) of the cranial, mid and caudal cervical esophagus (examination US 1).

\begin{tabular}{lccc}
\hline Measurement & Cranial & Mid & Caudal \\
\hline Depth (cm) & $2.37 \pm 0.48$ & $2.02 \pm 0.34$ & $2.00 \pm 0.41$ \\
Laterolateral width (cm) & $1.70 \pm 0.74$ & $1.29 \pm 0.26$ & $1.50 \pm 0.28$ \\
Dorsoventral height (cm) & $1.66 \pm 0.37$ & $1.62 \pm 0.40$ & $1.72 \pm 0.37$ \\
Surface area $\left(\mathrm{cm}^{2}\right)$ & $2.32 \pm 0.97$ & $1.74 \pm 0.54$ & $2.09 \pm 0.57$ \\
Wall non-distended (cm) & $0.28 \pm 0.07$ & $0.26 \pm 0.07$ & $0.23 \pm 0.04$ \\
Wall with tube (cm) & $0.20 \pm 0.07$ & $0.17 \pm 0.03$ & $0.14 \pm 0.03$ \\
Wall water bolus (cm) & & $0.20 \pm 0.03$ & $0.20 \pm 0.03$ \\
Wall concentrate bolus (cm) & & & $0.14 \pm 0.02$ \\
\hline
\end{tabular}




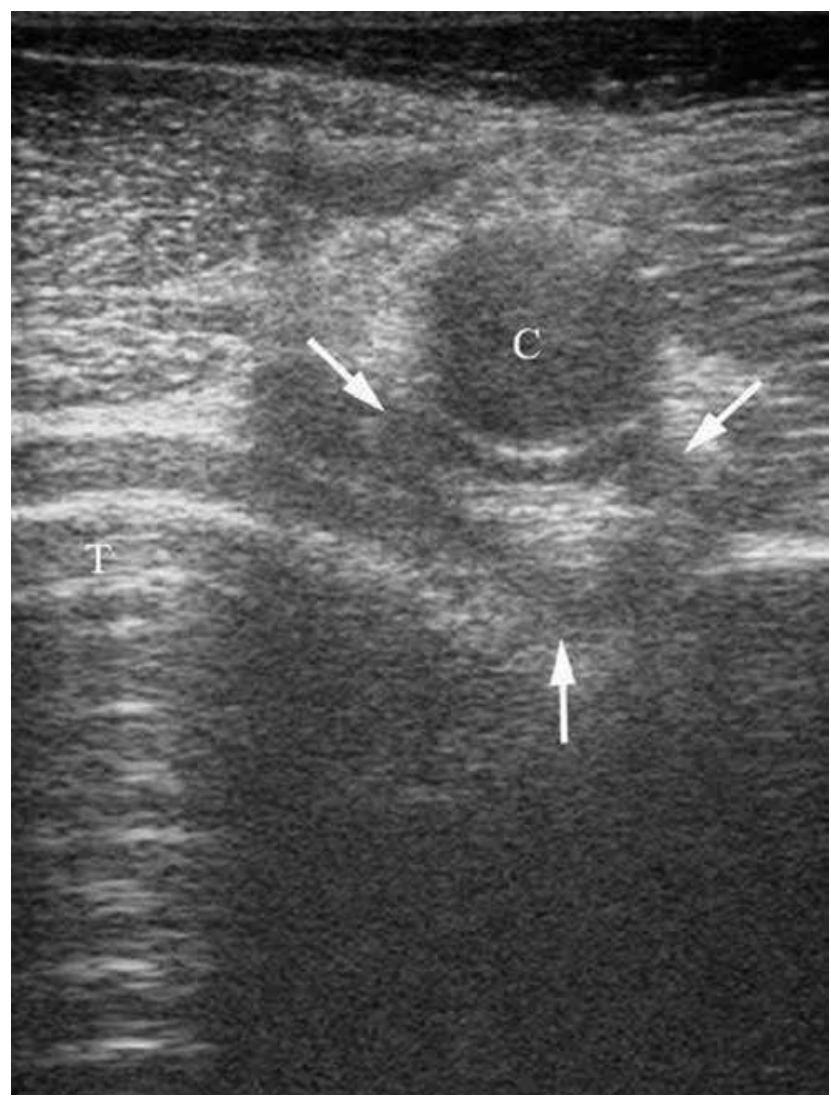

Figure 5. Sonogram of the caudal cervical esophagus (arrows). In this horse, the esophagus was located medial to the common carotid artery $(C)$ and dorsal to the trachea (T). This sonogram was obtained with a 7.5 MHz linear transducer at displayed depth of $6 \mathrm{~cm}$. The right side of the image is dorsal. (T: trachea).

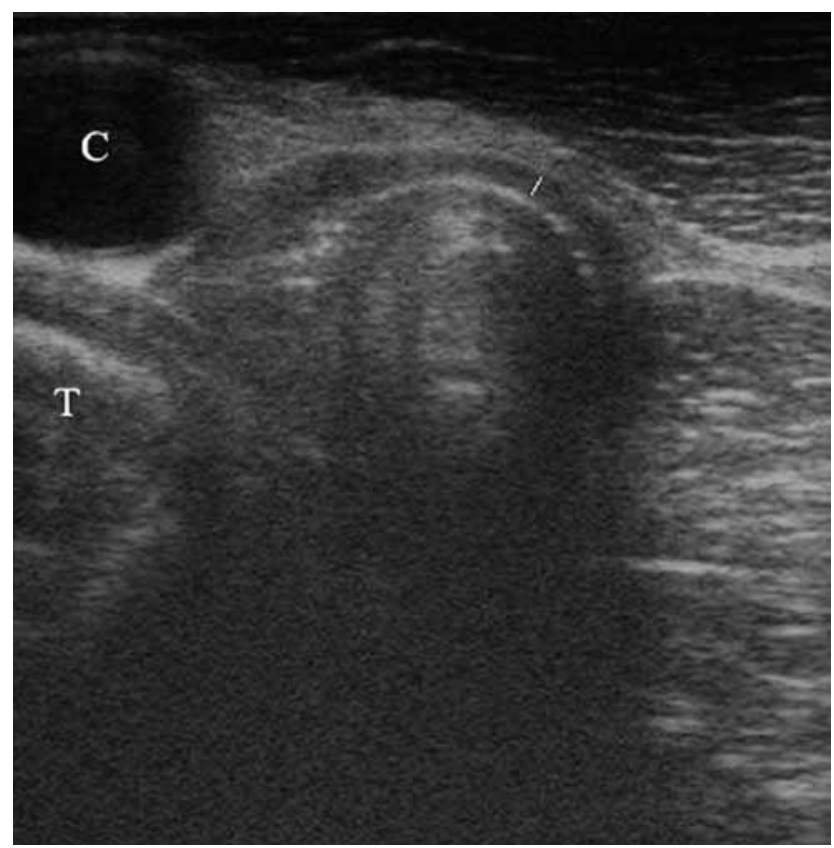

Figure 6. Sonogram of the caudal cervical esophagus taken after intubation. In this horse, the esophagus was located dorsal to the common carotid artery (C). Intubation facilitated wall measurement and made it less variable. This sonogram was obtained with a $7.5 \mathrm{MHz}$ linear transducer at displayed depth of $6 \mathrm{~cm}$. The right side of the image is dorsal. ( $T$ : trachea). at the thoracic inlet was seen (Table 2). In the caudal cervical region, immediately cranial to the scapula, the esophagus was U-shaped in five of the horses (horses 1, 2, 4, 5, 7), V-shaped in three of the horses (horses $6,8,10$ ) and straight (horizontal) in the two remaining horses (horses 3, 9) (Figure 3).

On the radiographs (view 3 ) taken during distention with barium in examination RX3, the esophagus straightened out in six horses (horses 1, 3, 4, 6, $7,9)$ and showed a small dorsal filling defect in four horses (horses 2, 5, 8, 10) (Figure 4). The mean time to complete contrast passage was 3.8 minutes (range 1-15 minutes) at the thoracic inlet in examination RX3. In eight of ten horses, the contrast medium had dis-appeared in less than 2.5 minutes. In horse 6 and horse 8 , the duration was 15 minutes and 8.5 minutes, res-pectively (Table 2). In examination RX4, the mean time to complete contrast passage was 1.7 minutes (range 1-6 minutes) at the thoracic part of the esophagus (view 5), and in 9 of 10 horses, the contrast medium had disappeared in less than 2 minutes. In horse 6 , there was also stasis of contrast medium seen in the thoracic esophageal part (6 minutes).

None of the horses showed signs of discomfort related to the administration of the contrast medium.

\section{Ultrasound}

\section{Anatomic topography}

On the native views of examination US1, the esophagus appeared as a hypoechoic polygonal shaped structure with an echogenic center and hypoechoic outer layer. The depth of the esophagus ranged from $1.3 \mathrm{~cm}$ to $3.5 \mathrm{~cm}$ measured from the skin on the left lateral side of the neck. The cranial part of the esophagus was located significantly deeper $(2.37 \pm$ $0.48 \mathrm{~cm})$ than the $\operatorname{mid}(2.02 \pm 0.34 \mathrm{~cm})$ or caudal part $(2.00 \pm 0.41 \mathrm{~cm})(\mathrm{P}<0.05)$ (Table 1).

In all of the horses, the course of the cranial part of the esophagus was similar: just caudal to the mandible, the esophagus was located in the sagittal plane, dorsal to the trachea and medial to the left common carotid artery. More caudally, at the most cranial standardized location, the esophagus was located more lateral towards the left side. In six of the ten horses, the esophagus was located dorsolateral to the trachea and ventromedial to the carotid artery and in four of the ten horses, it was located dorsolateral to the trachea and medial to the carotid artery. In the mid cervical region, the esophagus was located dorsolateral to the trachea and ventral to the left carotid artery in all horses (Figure 2). At the level of the thoracic inlet, the esophagus was positioned dorsolateral to the trachea and ventromedial $(n=3)$ (Figure 1), medial (Figure 5) $(n=1)$, dorsomedial $(n=4)$ or dorsal $(n=2)$ to the left common carotid artery.

In some of the horses, the anatomic relation to the left carotid artery changed after intubation (examination US3), whereby it became located medial, dorso- 
Table 2. Descriptions of the esophageal shape and measurements of the esophageal motility of the ten horses included in the study.

\begin{tabular}{|c|c|c|c|c|c|c|c|c|c|c|c|}
\hline \multirow[b]{3}{*}{$\mathrm{N}^{\circ}$} & \multirow[b]{3}{*}{ Breed } & \multirow[b]{3}{*}{ Sex } & \multirow[b]{3}{*}{ Age } & \multicolumn{5}{|c|}{ Radiography } & \multicolumn{3}{|c|}{ Ultrasonography } \\
\hline & & & & \multicolumn{3}{|c|}{ Shape } & \multicolumn{2}{|c|}{$\begin{array}{l}\text { Time contrast } \\
\text { disappearance }\end{array}$} & \multicolumn{2}{|c|}{$\begin{array}{l}\text { Duration } \\
\text { water bolus }\end{array}$} & \multirow{2}{*}{$\begin{array}{c}\begin{array}{c}\text { Duration } \\
\text { food bolus }\end{array} \\
\text { Thoracic } \\
\text { Inlet (s) }\end{array}$} \\
\hline & & & & Weigh & $\begin{array}{c}50 \mathrm{~mL} \\
\text { barium }\end{array}$ & $\begin{array}{c}2.5 \mathrm{~mL} / \mathrm{kg} \\
\text { barium }\end{array}$ & $\begin{array}{l}\text { Thoracic } \\
\text { Inlet (min) }\end{array}$ & $\begin{array}{l}\text { Thorax } \\
\text { (min) }\end{array}$ & $\begin{array}{c}\text { Mid- } \\
\text { Cervical(s) }\end{array}$ & $\begin{array}{l}\text { Thoracic } \\
\text { Inlet (s) }\end{array}$ & \\
\hline 1 & WB & M & 14 & 557 & U-shaped & Straight & 2 & 1.5 & 12 & 10 & 1 \\
\hline 2 & Trot & $\mathrm{G}$ & 12 & 555 & U-shaped & Indendation & 2.5 & 1 & 17 & 85 & 1.2 \\
\hline 3 & WB & M & 14 & 545 & Straight & Straight & 1.3 & 1 & 15 & 11 & 1.3 \\
\hline 4 & WB & M & 15 & 660 & U-shaped & Straight & 2 & 1 & 7 & 56 & 1.2 \\
\hline 5 & WB & M & 13 & 525 & U-shaped & Indendation & 1 & 1 & 10 & 9.5 & 1 \\
\hline 6 & Trot & M & 13 & 535 & V-shaped & Straight & 15 & 6 & 20 & 40 & 1.2 \\
\hline 7 & WB & G & 13 & 628 & U-shaped & Straight & 2 & 1 & 8.5 & 12 & 5.75 \\
\hline 8 & WB & M & 13 & 555 & V-shaped & Indendation & 8.5 & 1 & 17.5 & 67 & 1 \\
\hline 9 & Trot & G & 7 & 535 & Straight & Straight & 1 & 2 & 11 & 10 & 1 \\
\hline 10 & WB & G & 12 & 555 & V-shaped & Indendation & 2.5 & 1.25 & 11 & 31 & 1.2 \\
\hline
\end{tabular}

$\mathrm{WB}=$ Warmblood; Trot: Trotter; $\mathrm{M}=$ Mare; $\mathrm{G}=\mathrm{Gelding}$

medial or dorsal to the left carotid artery (Figure 6). The same change in location was often briefly seen during a peristaltic wave after a swallowing movement.

\section{Wall thickness}

In most of the present cases, only the left lateral esophageal wall could be clearly visualized due to hyperechoic content (air) in the lumen of the esophagus causing acoustic shadowing. On the native images (examination US1), the mean wall thickness was 0.28 $\pm 0.07 \mathrm{~cm}, 0.26 \pm 0.07 \mathrm{~cm}, 0.23 \pm 0.04 \mathrm{~cm}$ at the cranial, mid and caudal cervical location, respectively. The wall thickness decreased gradually from cranial to caudal with a significant difference between the cranial and caudal location $(\mathrm{p}<0.05)$.

At maximum distention during water bolus administration (examination US2), the mean wall thickness was $0.20 \pm 0.03 \mathrm{~cm}$ and $0.20 \pm 0.03 \mathrm{~cm}$ at the middle and caudal location, respectively. The mean wall thickness measured with the stomach tube in the esophagus (examination US3) was $0.20 \pm 0.07 \mathrm{~cm}$, $0.17 \pm 0.03 \mathrm{~cm}$ and $0.14 \pm 0.03 \mathrm{~cm}$ at the three standardized locations (Figure 6), respectively, with again a significant difference between the cranial and caudal location $(\mathrm{p}<0.05)$. At maximum distention after swallowing a bolus of concentrates (examination US4), the mean wall thickness was $0.14 \pm 0.02 \mathrm{~cm}$ at the caudal location (Table 1).

The coefficient of variation of measurements was smaller $(10 \%)$ in the recordings with intubation than in the native recordings $(15 \%)$, which indicates a better repeatability of the measurements after intubation.

Distention by intubation, water or concentrate bolus passage was a statistically significant factor $(p<0.05)$ affecting esophageal wall thickness. The wall of the esophagus was thinnest when distended by intubation or a bolus of concentrate. The wall distended by a bolus of water, was less thin than by intubation or concentrate but thinner than the not distended esophagus $(\mathrm{p}<0.05)$.

Surface area, laterolateral width and dorsoventral height

The surface area could only be measured on the native views (examination US1), since the stomach tube, water and food bolus caused too much acoustic shadowing to visualize the medial part of the esophagus. Even in examination US1, several attempts were necessary to see the full circumference of the esophagus, and in some cases, a virtual line had to be drawn in the far field to complete the full circumference of the esophagus. The mean surface area was $2.32 \pm$ $0.97 \mathrm{~cm}^{2}, 1.74 \pm 0.54 \mathrm{~cm}^{2}$ and $2.09 \pm 0.57 \mathrm{~cm}^{2}$ at the cranial, mid and caudal cervical location, respectively. The laterolateral width was $1.70 \pm 0.74 \mathrm{~cm}, 1.29$ $\pm 0.26 \mathrm{~cm}$ and $1.50 \pm 0.28 \mathrm{~cm}$ and the dorsoventral height $1.66 \pm 0.37 \mathrm{~cm}, 1.62 \pm 0.40 \mathrm{~cm}$ and $1.72 \pm$ $0.37 \mathrm{~cm}$ at the three standardized locations, respectively (Table1). Cranially, the esophagus appeared more oval-shaped with a laterolateral width significantly larger than at the other positions $(p<0.05)$. The surface of the esophagus was significantly smaller at the mid cervical part than at the cranial and caudal cervical part $(\mathrm{p}<0.05)$.

\section{Bolus passage time}

In examination US2, the bolus passage time in the mid cervical region was similar in all of the ten horses (mean: $13 \pm 4$ seconds) and significant stasis of water was never seen (Table 2). At the level of the thoracic 
inlet however, there was significant stasis of water in five out of ten horses (horses 2, 4, 6, 8 and 10), causing an increased mean passage time of $28 \pm 21 \mathrm{sec}-$ onds (range 7-122 seconds). In the horses where no stasis was noted, the mean was $11 \pm 1$ seconds (range 7-14 seconds). In 13 of thirty bolus administrations, water stasis disappeared immediately after a swallowing movement and a subsequent peristaltic wave (Table 2).

In examination US4, the mean bolus passage time was $1.6 \pm 1.6$ seconds. In all but one horse (horse 7), the bolus passed in less than 1.5 seconds. In this horse (horse 7), stasis was seen at the thoracic inlet. Therefore, more boluses were administered and the horse showed stasis in three of ten swallowed boluses. The stasis disappeared after a second swallowing movement at 15 seconds, 7 seconds and 28 seconds.

\section{DISCUSSION}

Contrast radiography has been described as an aid in diagnosing diverticula, strictures, mega-esophagus or motility disorders. In the literature, limited information is available on the normal equine esophagogram and different techniques have been used (Butler et al., 2000; Tillotson et al., 2010; Swain et al., 2004; Prutton et al., 2015; Broekman et al., 2002; Greet, 1982; Greet and Whitwell, 1986).

In the present study, the oral administration of 50 $\mathrm{mL}$ barium suspension (examination RX2) allowed visualization of the esophagus over its entire length with accentuation of the mucosal folds. A variation in the long-axis shape (U-shaped, V-shaped or straight) of the esophagus was seen at the thoracic inlet. The present study did not allow assessing if shape variations occurred in the same horse over time.

The usage of bigger volumes of barium $(2.5 \mathrm{~mL} /$ $\mathrm{kg} \mathrm{30 \%}$ barium) in examination RX3 and examination RX4 allowed full distention of the esophagus when the radiographs were taken during bolus administration, which might be helpful in the diagnosis of mild strictures. The disadvantage of this technique is that two boluses had to be administered to visualize the entire esophagus, which adds up to a large volume of barium administered. None of the horses showed signs of discomfort after examination. A possible alternative would be the use of a small amount of barium and insufflation of air to cause the required distention. Such double contrast esophagogram would also be safer in case of regurgitation and aspiration (Butler et al., 2000).

Greet (1982) described the presence of dorsal filling defects at the level of the thoracic inlet in three horses that showed significant stasis of contrast medium at the thoracic inlet after orally administered barium. In the present study, the same dorsal filling defects were seen at the thoracic inlet in four horses after the administration of $2.5 \mathrm{~mL} / \mathrm{kg} 30 \%$ barium
(Figure 4). This is probably a normal finding of a distended esophagus. The indentation is possibly caused by a mucosal fold (Greet, 1982) and it might be related to a change of the esophagus from a ventral direction to a dorsal direction.

The administration of $2.5 \mathrm{~mL} / \mathrm{kg} 30 \%$ barium didn't seem to be a trustworthy way to evaluate esophageal motility, since there was stasis and dilation of the esophagus at the thoracic inlet in several of the horses, and the time of contrast medium clearance varied between horses. The mean time of contrast medium disappearance at the level of the thoracic inlet is longer than at the thoracic level. This difference might have been underestimated due to the study design, because the first radiograph after bolus administration was taken after approximately one minute. In eight out of ten horses, the contrast medium had already disappeared completely in the thoracic part when the first radiograph was taken, while at the level of the thoracic inlet, this was only in two out of ten horses. The contrast medium passage time in horse 6 was much longer, both at the thoracic inlet (15 minutes) and at the thoracic part ( 6 minutes). In some of the horses, additional stasis of contrast medium was seen cranial to the cardiac silhouette, but since the penetration of the radiation at this level was not sufficiently constant on every radiograph, this was not included in the study.

Ultrasonography of the esophagus is an easy-toperform and non-invasive examination that can be of potential value in esophageal disease. It has been described as an aid in diagnosing esophageal obstructions, esophageal tears, diverticula, esophagitis or an esophageal inclusion cyst (Reef, 1998; Magri et al., 2014; Kruger and Davis, 2013; Prutton et al. 2015; Whelchel et al., 2010; Woodfort et al., 2010). As in human medicine, the oral administration of an ultrasound contrast agent, outlining the esophageal mucosa, could be of additional value to avoid necessitating the radiation of a barium esophagogram (Cui et al., 2015).

The present study confirms that the esophagus is located in the sagittal plane in the cranial part of the neck and that it is located left of the trachea in the middle and caudal thirds of the neck. The location of the esophagus to the right of the trachea, as described in the literature (Magri et al., 2014; Reef, 1998), was not seen in any of the horses.

Reef (1998) described the esophagus as a tubular structure with a 3 to $4 \mathrm{~mm}$ thick wall. In the present study, the average wall thickness of the non-distended esophagus was $2.6 \pm 0.3 \mathrm{~mm}$, and significant differences were seen depending on the location. A larger population should be evaluated to determine exact reference values. Measurements of the wall of the non-distended esophagus showed the greatest variability, and it was difficult to measure at a consistent location along the esophageal wall (Figure 2). Additionally, the wall thickness of the distended esophagus 
was also measured, because it mimics the situation of a distended esophagus in diseased state, such as during an obstruction or with a diverticulum. Distention due to intubation or due to a water or concentrate bolus resulted in a decrease in wall thickness, and it facilitated measuring with less variation.

Judging esophageal motility with a bolus of water administered by intubation did not prove to be a valuable test. Although intubation allowed the administration of a standardized amount, the time of bolus administration differed between horses due to a difference in flow through the esophagus. At the mid cervical level, no stasis was seen, since the bolus seemed to travel down easily by means of gravity. At the thoracic inlet however, there was an important variation in the bolus passage time and it was clear that this passage time was greatly influenced by the occurrence of a swallowing action and subsequent peristaltic wave. These findings could also explain the prolonged presence of barium at the thoracic inlet seen during radiographic examination, when no attention was paid to swallowing movements. Even though a horse doesn't swallow a standardized amount of food, the administration of spontaneously swallowed concentrate seemed to be the most reliable way to assess the motility of the esophagus at the level of the thoracic inlet. The delayed passage of all three boluses (barium, water and contrast) was not consistently found in the same horses, which suggests that motility might be variable within a horse or that the different tests might produce different results. Video fluoroscopy probably remains a superior method to evaluate esophageal motility, since one bolus can be followed over the entire length of the esophagus, also in the thoracic part (Greet, 1982; Greet and Whitwell, 1986). Greet (1982) demonstrated with the use of an image intensifier that a bolus of $60 \mathrm{~mL}$ barium suspension should pass to the stomach in four to ten seconds. The disadvantage however is the complexity of the procedure, the availability of the technique and mainly the increased radiation exposure to patient and radiographers.

Limitations of this study include the small number of horses and the lack of fluoroscopic evaluation as a golden standard. In addition, the registration of swallowing movements during radiographic examination could have altered the interpretation of the results.

\section{CONCLUSION}

In this study, more insight into the radiographic and ultrasonographic evaluation of the normal esophagus is provided. Stasis seen at the thoracic inlet after bolus administration by intubation should not be regarded as an abnormal finding and swallowing has a large influence on the bolus passage time.

\section{REFERENCES}

Broekman L. E. M., Kuiper D. (2002). Megaesophagus in the horse. A short review of the literature and 18 own cases. The Veterinary Quarterly 24(4), 199-202.

Butler J. A. Oesophagus (2000). Butler J. A., Colles C. M., Dyson S.J., Kold S. E., Poulos P.W. (editors). In: Clinical Radiology of the Horse. Second edition, Blackwell Publishing Company, Oxford, p. 531-547.

Clark E.S., Morris D.D., Whitlock R.H. (1987). Esophageal manometry in horses, cows, and sheep during deglutition. American Journal of Veterinary Research 48(4), 547-551.

Cui X.W., Ignee A., Baum U., Dietrich C. F. (2015). Feasibility and usefulness of using swallow contrast-enhanced ultrasound to diagnose Zenker's diverticulum: preliminary results. Ultrasound in Medicine \& Biology 41(4), 975-981.

Feige K., Schwarzwald C., Fürst A., Kaser-Hotz B. (2000). Esophageal obstruction in horses: a retrospective study of 34 cases. The Canadian Veterinary Journal 41(3), 207-210.

Greet T. R. (1982). Observations on the potential role of oesophageal radiography in the horse. Equine Veterinary Journal 14(1), 73-79.

Greet T. R., Whitwell K. E. (1986). Barium swallow as an aid to the diagnosis of grass sickness. Equine Veterinary Journal 18(4), 294-297.

Hillyer M. (1995). Management of oesophageal obstruction ("choke") in horses. In Practice 17(10), 450-457.

Jones S. L., Blikslager A. T. (2004) Esophageal diseases. In: Reed S.M., Baily W. M. and Sellon D. C. (editors). Equine Internal Medicine. Second edition, Saunders Missouri, p. 855-863.

King J. N., Davies J. V., Gerring E. L. (1990). Contrast radiography of the equine oesophagus: effect of spasmolytic agents and passage of a nasogastric tube. Equine Veterinary Journal 22(2), 133-135.

Kruger K., Davis J. L. (2013). Management and complications associated with treatment of cervical oesophageal perforations in horses. Equine Veterinary Education 25(5), 247-255.

Magri M. (2014) Ultrasonography of the Soft Tissue Structures of the Neck. In: Kidd J.A., Lu K.G., Frazer M.L. (editors) Atlas of Equine Ultrasonography. John Wiley \& Sons. Chichester, p. 466-470.

Meyer G. A., Rashmir-Raven A., Helms R. J., Brashier M. (2000). The effect of oxytocin on contractility of the equine oesophagus: a potential treatment for oesophageal obstruction. Equine Veterinary Journal 32(2), 151-155.

Ploeg M., Gröne A., Saey V., de Bruijn C.M., Back W., van Weeren P.R., Scheideman W., Picavet T., Ducro B.J., Wijnberg I., Delesalle C. (2014) Esophageal Dysfunction in Friesian Horses: Morphological Features. Veterinary Pathology 51(5), 979-985.

Prutton J. S. W., Marks S. L., Aleman M. (2015). Endoscopic Balloon Dilation of Esophageal Strictures in 9 Horses. Journal of Veterinary Internal Medicine 29(4), 1105-1111.

Reef V.B. (1998) Ultrasonographic evaluation of small parts. In Reef V.B.(editor). Equine Diagnostic Ultrasound. W.B. Saunders Co., Philadelphia. p. 489-491. 
Stick J.A., Derksen F.J., McNitt D.L., Chou C.C. (1983). Equine esophageal pressure profile. American Journal of Veterinary Research, 44(2), 272-275.

Swain J., McGorum B., Scudamore C., Pirie R. (2004). Persistent oesophageal obstruction (choke) associated with a diverticulum of the terminal oesophagus in a pony. Equine Veterinary Education 16(4), 195-198.

Tillotson K., Traub-Dargatz J. L., Twedt D. (2010). Balloon dilation of an oesophageal stricture in a one-monthold Appaloosa colt. Equine Veterinary Education 15(2), 67-71.

Watson T., Sullivan M. (1991). Effects of detomidine on equine oesophageal function as studied by contrast radiography. Veterinary Record 129(4), 67-69.
Whelchel D., Arnold C., Chaffin K. (2010). Ante mortem diagnosis of necrotising emphysematous oesophagitis and gastritis in a horse. Equine Veterinary Education 22(9), 451-455.

Woodford N. S., Randle T. J. L., Mccluskie L. K. (2010). Diagnostic investigation and surgical management of an oesophageal mural inclusion cyst in a pony yearling. Equine Veterinary Education 22(4), 165-169.

Wooldridge A. A., Eades S. C., Hosgood G. L., Moore R. M. (2002). Effects of treatment with oxytocin, xylazine butorphanol, guaifenesin, acepromazine, and detomidine on esophageal manometric pressure in conscious horses. American Journal of Veterinary Research 63(12), 17381744.

\section{Uit het verleden}

\section{DIEREN ALS DRAGERS VAN CULTUUR}

De Cleene, M., De Keersmaeker, J.P., Compendium van Dieren als dragers van Cultuur. Deel 1. Zoogdieren, pp. 1047, €95; Deel 2. Vogels, pp. 816, €85; Deel 3. Vissen, reptielen, amfibieën, ongewervelden, fabeldieren, pp. 776, $€ 85$. De drie delen samen in cassette: $€ 249$. Uitgegeven door Mens \& Cultuur, Gent.

$\mathrm{Na}$ het Compendium van rituele planten in Europa (1337 pagina's) voltooide Marcel De Cleene met coauteur Jean Pierre de Keersmaeker een nog imposanter werk: drie forse boekdelen met een onvoorstelbaar grote hoeveelheid degelijke informatie over het dier in onze cultuur.

Zelfs in tijden van Google en Wikipedia is dit niet te missen voor wie het zich kan permitteren (of laten cadeau doen). De consistente benadering van het onderwerp in zoveel verschillende diersoorten biedt onschatbare voordelen. Wat komt er immers niet allemaal aan bod: cultus, symboliek, volksgeloof, volksgebruiken en volksgeneeskunde, legenden, magie, psychologie, biologische en taalkundige weetjes en niet te vergeten kunst. Dit niet enkel voor wat betreft inheemse dieren, maar ook voor de meest tot de verbeelding sprekende uitheemse dieren, tot en met fabeldieren. Volkskunde toegepast op dieren: voor ons ontlenen de dieren hun waarde immers - anthropocentrisch als we zijn - aan ons eigen persoontje behorend tot een in recordtempo maatschappelijk bijzonder complex geëvolueerde zoogdiersoort Homo sapiens.

Voor wie het zich niet kan voorstellen hoe de onderwerpen behandeld en gepresenteerd worden, geven we een willekeurig voorbeeld: eekhoorns. $\mathrm{Na}$ een ultrakorte presentatie van de familie met 280 soorten, waarvan 11 in Europa, komt als eerste aan bod de eekhoorn in rituelen, mythologie en devotie bij de Germanen, heel kort bij de Kelten en bij de bewoners van MiddenAmerika en het Verre Oosten. Volgen: de eekhoorn als symbool van zowel deugdzaamheid als zonde (zelfs van de duivel), van gulzigheid, van gierigheid en van goddelijke voorzienigheid; de eekhoorn in de kunst en als embleem, in de magische wereld, in volksgeloof en volksgeneeskunde. Het hoofdstukje sluit af met een eekhoorntjesdroom en een weetje over de Noord-Amerikaanse Grijze Eekhoorn die in Europa de inheemse Rode Eekhoorn verdringt. 